\title{
Review
}

\section{Innate Immune and Fungal Model of Alzheimer's Disease}

\author{
Bodo Parady ${ }^{\mathrm{a}, \mathrm{b}, *}$ \\ ${ }^{a}$ Children's Hospital Oakland Research Institute, Oakland, CA, USA \\ ${ }^{\mathrm{b}}$ Visiting Scholar, University of California, Berkeley, Berkeley CA, USA
}

Accepted 29 June 2018

\begin{abstract}
Various fungi and bacteria can colonize in the brain and produce physical alterations seen in Alzheimer's disease (AD). Environmental and genetic factors affect the occurrence of fungal colonization, and how fungi can grow, enter the brain, and interact with the innate immune system. The essence of $\mathrm{AD}$ development is the defeat of the innate immune system, whether through vulnerable patient health status or treatment that suppresses inflammation by suppressing the innate immune system. External and mechanical factors that lead to inflammation are a door for pathogenic opportunity. Current research associates the presence of fungi in the etiology of $\mathrm{AD}$ and is shown in cerebral tissue at autopsy. From the time of the discovery of $\mathrm{AD}$, much speculation exists for an infective cause. Identifying any $\mathrm{AD}$ disease organism is obscured by processes that can take place over years. Amyloid protein deposits are generally considered to be evidence of an intrinsic response to stress or imbalance, but instead amyloid may be evidence of the innate immune response which exists to destroy fungal colonization through structural interference and cytotoxicity. Fungi can remain ensconced for a long time in niches or inside cells, and it is the harboring of fungi that leads to repeated reinfection and slow wider colonization that eventually leads to a grave outcome. Although many fungi and bacteria are associated with $\mathrm{AD}$ affected tissues, discussion here focuses on Candida albicans as the archetype of human fungal pathology because of its wide proliferation as a commensal fungus, extensive published research, numerous fungal morphologies, and majority proliferation in AD tissues.
\end{abstract}

Keywords: Alzheimer's disease, APOE, Candida albicans, fungi, innate immune system, LCAT

\section{INTRODUCTION}

Alois Alzheimer described the first case of Alzheimer's disease (AD) in 1906 in the eponymous female Auguste D. [1, 2], and found abnormal deposits of amyloid protein plaques (amyloid beta, or $\mathrm{A} \beta$ ) and fibrous protein tangles (neurofibrillary tau) which were considered the cause of neural deterioration. A 1939 review speculated on various causes of $\mathrm{AD}$ [3], including constitution, aging related atrophy, and an association with inflammatory conditions,

\footnotetext{
*Correspondence to: Bodo Parady, PhD, Sphinx Pharma, Inc., Suite 299, 696 Danville Blvd., Danville, CA 94526, USA. E-mail: boparady@yahoo.com.
}

noting the development of plaques near the site of previous trauma mentioning "intercurrent infection", hinting that frequent infection is a component of AD. Dementia can directly result from diffuse axonal injury, identified as a sequela of traumatic brain injury in the 1950s [4], and AD is a known sequela of brain injury [5]. Diffuse axonal injury can manifest punctate hyaline masses known as corpora amylacea, a polyglucosan disease [6]. Corpora amylacea develop independently in the brain tissue of $\mathrm{AD}$ patients [7-9], and because corpora amylacea stain antifungal antibodies, fungi are implicated [10]. A 1955 study of identical twins with one of a pair that develops $\mathrm{AD}$ emerging after development of rosacea, suggests an infectious etiology [11]. The association of AD 
with infectious processes is now a current topic [12]. There are genetic associations of frequency and age of onset of $\mathrm{AD}$, which is associated with physical, gradual damage to the brain leading to memory loss and slower thought processes, and ultimately death [13]. AD incidence increases exponentially with age with the highest rates in North America and Europe and increases most for patients in their 60s and 70s [14].

The fungal model refers to the 2014 Carrasco et al. fungal etiology based on AD autopsies which exhibit fungi only in affected neural tissue [10, 15-18] and evidence that fungal infection is etiological for AD was updated by Carrasco et al. [19]. Fungal genera found in AD associated tissues identified by modern sequencing methods include yeasts, filamentous fungi, and saprophytes appropriate to infections and allergic reactions in humans [20]: Alternaria, Botrytis, Candida, Cladosporium, Fusarium, and Malassezia. Candida (the most widespread) antibodies tested positive in $89.6 \%$ of $\mathrm{AD}$ patient serum compared to $8.8 \%$ for controls [17]. Recently many bacteria have been found in AD brain tissue [21, 22], of which some are associated with mucosal C. albicans biofilms: Burkholderia and Pseudomonas [23]; Firmicutes (dentures [24]); Staphylococcus epidermidis [25]; Stenotrophomonas maltophilia [26].

\section{A $\beta$ hypothesis for Alzheimer's disease}

Amyloid peptide accumulation is associated with a number of diseases, affecting various organs. George Glenner postulated that $A \beta$, with $A \beta_{42}$ associated with $\mathrm{AD}$, is a cause of $\mathrm{AD}$ [27]. $\mathrm{AD}$ causation is controversial, and Selkoe and Hardy [28] offer the hypothesis that genetic mutations near the $A \beta$ section of amyloid- $\beta$ protein precursor (A $\beta \mathrm{PP})$ are associated with rapid onset of $\mathrm{AD}$ and increasing $\mathrm{A} \beta$ deposits in memory and cognitive centers. Conversely, a mutation that reduces A $\beta P P$ is viewed as protective of neural decline [29].

The pathological changes in $\mathrm{AD}$ are associated with neurofibrillary tangles, neuropil threads, and hyperphosphorylated tau [30]. The developing view is that the histological evidence of $A \beta$ and hyperphosphorylated tau deposits may not represent a cause but may be the effect of developing AD [31]. There is a poor relationship between the manifest progression of $\mathrm{AD}$ which do not correspond to the histological evidence of lesion formation of amyloid plaques [32].

Amyloid deposition is associated with fungal disease and can begin with the deposition of serum amyloid P (SAP) onto C. albicans cells [33, 34], or other Candida species [35]. Peptide binding characteristic of $C$. albicans produces adhesive affinity colonization $[36,37]$ and is characteristic of all invasive morphologies of $C$. albicans: yeasts, hyphae, and pseudohyphae [33]. Surface amyloids expressed by $C$. albicans during infection induce binding by SAP which blocks the inflammatory response and adhere to SAP with fungal colony expansion stretching human cell surface proteins which copiously extrude amyloids [33]. No evidence exists that the presence of SAP increases the risk and development of $\mathrm{AD}$, but as $\mathrm{AD}$ develops, $\mathrm{SAP}$ levels drop in the cerebrospinal fluid (CSF), perhaps because SAP adherence to fungal cells removes SAP from the CSF and plasma [38].

That the upregulation of $\mathrm{A} \beta \mathrm{PP}$ following traumatic brain injury is protective indicates that the processes associated with $A \beta$ are not entirely pathogenic [32]. The pathological deposition of $A \beta$ after administration of sevoflurane anesthetic [39] offers a window into pathogenesis. Sevoflurane is associated with intestinal reperfusion injury and loss of intestinal mucosal barrier function [40]. Loss of intestinal barrier function leads to the opportunity for persorption of bacteria and fungi into the circulatory system [41] and thus ability to colonize in the neural cells of the brain. The innate immune response in the brain generates $\mathrm{A} \beta$ which inhibits the growth of $C$. albicans [42, 43]. Animal models in mice and worms along with cell cultures validate that $A \beta$ inhibits the growth bacteria and fungi [44]. Conversely, treatments for $\mathrm{AD}$ are often aimed at reducing the deposits of $A \beta$ in the brain $[45,46]$. Interfering with the innate immune response to reduce the inflammatory response often aggravates the infection producing inflammation (e.g., use of corticosteroids to relieve inflammation in infections $[47,48]$ ), and reduction of $A \beta$ (an inflammatory agent) in clinical trials has resulted in aggravation of $\mathrm{AD}[49,50]$.

\section{Tau phosphorylation}

Tau phosphorylation (hyperphosphorylation) of proteins and the resultant degeneration (tauopathy) through the formation of tangles was early historical physical evidence of AD [51]. Tyrosine phosphorylation corresponds to tau aggregation or tangling [52]. Although hyperphosphorylated tau tangles have a pathological appearance, neuronal cells can survive more than 20 years with extensive tangles [53], and tau filamentation is neuroprotective [54]. 


\section{Cholinergic model of memory dysfunction}

Loss of cognition is due to loss of central nervous system function where the hypothetical key is the disruption of the cholinergic neurotransmitter system, the "cholinergic hypothesis" [55]. In animal studies, changes in choline and acetylcholine are associated with behavior. The growth of $C$. albicans varies with the availability of choline, because choline reduces the need to synthesize PC which is energetically favorable over synthesis via the salvage pathway [56, 57]. Because the brain intracellular space has about 6 times the concentration of choline than blood plasma and 10 times that of the CSF [58], invagination into brain cells becomes the preferred environment for $C$. albicans.

\section{FUNGI AND RELATION TO ALZHEIMER'S DISEASE}

C. albicans, the most prolific and morphologically diverse fungal species in humans, was described by Hippocrates as thrush, a formation of white plaques inside the mouth [59] and was isolated by Bennett in 1844 in the sputum of tuberculosis patients, and by Zenker in 1861 from a brain infection in a debilitated patient having spread from thrush lesions [60]. Zenker's report was interpreted as referring to Cryptococcus neoformans [61] often confused with C. albicans. When carried in the bloodstream as yeasts from the intestines, $C$. albicans the most common commensal fungus can readily infect various organs, and can colonize inside both resident cells and immune cells (macrophages) as endomycosomes or phagosomes [15]. Other pathogenic fungi can affect hosts similarly, including Cryptococcus gattii [62], Aspergillus spp. [63], and molds [64]. Carrasco et al. first published postmortem evidence that fungi cause $\mathrm{AD}$ in 2014 [15].

C. albicans may be partially symbiotic because of the genes for the glyoxylate cycle and gluconeogenesis which are suppressed by glucose concentrations found in vivo [65], but when C. albicans is phagocytosed by macrophages and neutrophils, these paths become expressed. The glyoxylate cycle produces glucose from fatty acids and glucose is needed in large quantities to enable $C$. albicans growth [66]. These fatty acids can be cytotoxic or suppressive to microbes; a mechanism in C. albicans that converts fatty acids to glucose, which is key to the virulence of C. albicans [67], could also be of biological advantage in human starvation, taking stored fats and converting them to glucose.

\section{Candida albicans morphologies}

The virulence of $C$. albicans is aided by its interchange between four morphologies [68]. C. albicans can appear as a 2 to 8 micron unicellular yeast (blastoconidia) that can grow in a colony, and when they bud can lengthen into chains with constrictions (pseudohyphae). Germ tubes appear from single cells and extend to the first constriction, perhaps form hyphae which are important for invasion and pathogenesis. C. albicans blastoconidia are less hydrophobic than germ tubes [69] making germ tubes resistant to phagocytosis by macrophages and monocytes, and makes $C$. albicans more virulent [70].

Giant blastoconidia, an unusual form of C. albicans, called chlamydoconidia (8 to 12 microns in diameter), result from inflammatory responses and are found in cardiac, kidney, cartilage, or bronchial vegetations [71]; application of antifungals may induce their formation. Chlamydoconidia are important because they have been confused with Cryptococcus neoformans [72, 73].

\section{Virulence}

Primary virulence factors of C. albicans are: conversion of yeast-like cells to hyphae [74], lytic secretions (aspartyl proteases [75], lipases, and phosphatases) and cell surface proteins [76] which enable adhesive penetration, persorption, or phagocytosis [77]. To enable the commensal C. albicans to invade requires overwhelming either impaired or normal innate immunity or the means to block innate immunity [78] such as aspartyl proteases which block the complement system increasing virulence [79]. In oral thrush, $C$. albicans invades endothelial epithelial cells by both endocytosis and penetration [80]. Virulence in the intestines is by proteolytic penetration which aspartyl protease inhibitor pepstatin blocks [81]. C. albicans prevents removal by the immune system by maintaining low levels of colonization (commensal) which avoids activating the MAPK alarm pathway [82]. As the fungal burden increases, the ensuing hyphal development activates cytokines that recruit macrophages and neutrophils. As the immune response clears the fungal burden, the colony falls below the virulent state returning to the commensal state [83]. 


\section{Yeast to hyphal transition}

The yeast to hyphal transition is associated with the virulence of $C$. albicans because of the invasion of epithelial cells by hyphae and pseudohyphae. A C. albicans cytolytic protein, "Candidalysin", invades the epithelium, kills cells, and blunts the immune response [84]. C. albicans adapts to the environment inside macrophages by making the yeast to hyphal transition, a defense against pyroptosis: The macrophage cell death mechanism that attacks pathogens with immune responses to block replication [85]. Macrophages phagocytose $C$. albicans as part of the immune response, inducing $C$. albicans to alter its metabolism in response the environment, and to develop hyphae, which in turn induces macrophage pyroptosis thereby enabling C. albicans to escape [86, 87] and to induce massive killing of macrophages after this first phase, a non-pyroptotic macrophage death.

In $\mathrm{AD}$, the hazard is the immune evasion of Candida spp. (C. spp.) by hiding inside endothelial cells [88] whereby a victim cell is induced to extend a pseudopod to endocytose the fungal cell. Binding to the endothelium was demonstrated for germ tubes and buds inside the cells, forming pseudohyphae without any changes to the morphology of the endothelial cells [89]. In acidic conditions, $C$. albicans can raise $\mathrm{pH}$ from 4 to over 7 within 12 hours, which results in self-induction of the yeast to hyphal transition [90]. In the case of glucose deprivation, the pathway to raise $\mathrm{pH}$ is the general degradation and proteolysis of proteins to produce ammonia [91], a base for which C. albicans has a more powerful reaction to acidity than other fungi. Excessive ammonia is found in the CSF and blood of AD patients [92] which produces pathologies during glucose deprivation such as metabolic dementia [93].

\section{Growth in saliva and glucose}

Low submandibular saliva flow is associated with moderate to advanced $\mathrm{AD}$ [94] and may be the result of deterioration of the nerves serving the submandibular salivary glands, possibly associated with C. albicans infection. Conversely, dementia's effect on executive function results in poor hygiene [95] may increase $C$. albicans growth. $C$. albicans does not normally grow in saliva, but its growth can be stimulated by higher levels of dietary glucose or serum glucose as found in diabetes patients [96]. Normally bacteria break down glucose in saliva, but antibiotics that kill the bacteria, or glucocorticosteroids, can stimulate the growth of $C$. albicans [97].

\section{C. albicans lipases}

The lipolytic enzymes of $C$. albicans provide fatty acids and glycerol as a food and energy source [98] and create an advantage for maintaining growth in the intestine and skin, and enabling acidification which contributes to virulence and tissue damage. The action of $C$. albicans lipases [99] produce lipid droplets in macrophages becoming foam cells hepatocytes becoming, and thereby induce cytotoxicity [100]. The effect of $C$. albicans lipase on the liver (the initial defensive organ against invasion from the gut and circulation by taking up the fungal cells) can induce nonalcoholic steatohepatitis, and under stress, causes liver damage [101]. The development of hepatic encephalitis associated dementia and the onset of $\mathrm{AD}$ should be examined as parallel, not separate, disorders.

\section{Calcineurin}

Calcineurin is a $\mathrm{Ca} 2+$ serine/threonine protein phosphatase activated by calmodulin that regulates processes in eukaryotes ranging from yeasts to humans [102]. C. albicans expresses calcineurin which is essential to virulence [103] and, in yeasts, it regulates cell cycle progress, the action of polarization in growth, and $\mathrm{Na}+$ and $\mathrm{Cl}-$ ions and $\mathrm{pH}$. Calcineurin in the human brain has a regulatory function similar to that of yeasts and is associated with the pathologies of dementia [104]. Levels of calcineurin increase greatly as one ages or suffers from injury or infection, and high levels of calcineurin are found in the astrocytes of the hippocampus in a mouse model for $\mathrm{AD}$, and in human $\mathrm{AD}$ patients [105].

Application of calcineurin inhibitors (cyclosporine and tacrolimus) to a murine model of $\mathrm{AD}$ was protective, perhaps even slowing or reversing the progression of AD [106]. A study of kidney transplants with fungal involvement showed a decreased probability of $\mathrm{AD}$, likely due to the chronic administration of calcineurin inhibitors (tacrolimus and cyclosporine) used to limit and control tissue rejection [107]. Tacrolimus is recognized as an antifungal [108] suggesting a connection because kidneys and brains are receptacles of fungi [109]. 


\section{Tyrosine phosphorylation}

In the bloodstream, C. albicans induces endocytosis by stimulating tyrosine phosphorylation endothelial proteins of 80 and $82 \mathrm{kDa}$ [110], and thus hyperphosphorylation may be evidence of invasion and induction by $C$. albicans, and is independent of $A \beta$ deposition which has been suggested as dependent on introduction and formation of $A \beta$ [111]. Belanger et al. show that the tyrosine kinase inhibitors genistein and tyrophostin 47 reduced phosphorylation as $C$. albicans endocytoses.

\section{Fungal markers associated with $A D$}

Chitins, chitinase, fungal proteins, and fungal antibodies may be excellent biomarkers of AD if fungi are etiological. Chitinase appears in humans in response to allergens (many of which contain fungi) and fungal pathogens. Since there are no external sources for chitinase in the CSF, the presence of chitinase signals fungal infection [112]. Chitin-like polysaccharides are an integral component of the amyloid plaques and amyloid angiopathy of AD [113], as demonstrated by colocalized calcofluor staining of $\mathrm{AD}$ plaques, chitinase treatment, and subsequent fluorescence decrease indicating that plaques contain fungal cells or detritus. Subsequently, more accurate immuno-staining was used to identify chitins, and two fungal proteins, enolase and $\beta$-tubulin in the brain tissue of AD patients [18].

\section{Chitotriosidase}

Elevated levels of chitotriosidase, a human chitinase enzyme, are a marker for $\mathrm{AD}$ and cerebrovascular dementia [114] and are associated with the deposition of $A \beta$ without observation of fungal infection. Chitotriosidase is produced by activated macrophages associated with ischemic cardiovascular disease (CVD) and AD. Detection of chitinase activity in the CSF with an accuracy of $86 \%$ is a superior $\mathrm{AD}$ marker than $\mathrm{A} \beta$ or tau both at $78 \%$ [112], where $A \beta$ is likely an immune response to a C. albicans infection [115]. YKL-40 (chitinase-3like protein 1) is a superior marker for AD [116]. Radiolabeled detection of chitin using ${ }^{123}$ I-chitinase functioned well as a radioligand for detection of fungal infections in mice [117]. In a neonate study of chitotriosidase produced by phagocytes in response to bacterial and fungal infections, there is a population of $6 \%$ that cannot express chitotriosidase for which one would expect a lowered ability to fight chitin containing pathogens [118], and note the high $50 \%$ level of false negative fungal cultures.

\section{Beta glucans}

Beta glucans are $\beta$-D-glucose polysaccharides found in plant, bacteria, and fungi/yeast cell walls, and are a marker for infection which can temper the immune response facilitating fungal survival [119]. Disseminated fungal infections seen in AD patients are associated with the widespread observation of beta glucans which are seen in serum along with antibodies for yeast and fungi species [17, 112, 120]. Finding the fungal $(1,3)-\beta$-glucan becomes evidence for disseminated infection, and when it is found in the CSF, it is a marker for CNS fungal infection [121, 122].

\section{IMMUNE SYSTEM}

The primary cells responsible for the removal and destruction of $C$. albicans cells are the neutrophils and macrophages. Neutrophils are found to execute the effect of TNF- $\alpha$ in the course of systemic candidiasis [123], and according to the ARTEMIS survey various C. spp. are found [124]. A review of neutrophil and macrophage activity finds that neutrophils kills $C$. albicans intracellularly and extracellularly, and blocks germ tube formation [125]; in fungal carbohydrate starvation, the glyoxylate cycle and the nitric oxide (NO) stress response are upregulated only when neutrophils phagocytose the fungus, while the oxidative stress response (superoxide dismutase or glutathione reductase) is active intracellularly and extracellularly [126].

\section{Nasopharyngeal defense}

Nasal mucosal secretions are the first defense against microbial intrusion with various proteins and lipids. The most hydrophobic lipids are generally more anti-microbial, in particular cholesteryl linoleate, and cholesteryl arachidonate [127]. These non-polar lipids are most effective against bacteria, but because $C$. albicans biofilms are combinations with bacteria, often MRSA, inhibition of bacteria effects diminution of biofilms, and thus an indirect reduction in overall $C$. albicans colonization [128-130]. There have been several cases of various fungal infections, mostly mucormycoses associated with diabetes, where hyphae have travelled through the neural cells to the brain $[131,132]$. Invagination of 
the blood vessel walls are directly involved in mycotic aneurysms [133].

\section{Dose related cerebral mycosis}

A 1978 survey showed C. albicans to be the predominant cerebral mycosis [134] and corrected the mistaken diagnosis of Cryptococcus spp. infection reported in previous surveys. The authors warned that C. albicans in large numbers from any site "portends infection of the central nervous system." Systemic C. albicans infections are associated with immunocompromised patients, but high doses of $C$. albicans can establish infection in immunocompetent subjects. One experiment administering $10^{12}$ cfus of C. albicans orally (comparable to the intestinal fungal colonization of patients treated with broad-spectrum antibiotics) on a healthy volunteer resulted in systemic fungemia caused by persorption of $C$. albicans cells across the intestinal wall [41].

\section{Role of $A \beta$ as an antifungal}

Formation of $A \beta$ is likely a direct innate immune response to $C$. albicans because $\mathrm{A} \beta$ is most specifically antimicrobial for $C$. albicans among organisms tested [115], and thus protects against infection in the brain; this action is directly contrary to efforts to reduce $A \beta$ and thereby reduce $A D$ damage. In addition, $A \beta$ reduces $E$. coli growth by 200 times in vitro, along with general antibacterial effects [135]. Reduction of $A \beta$ in $A D$ patients appears to have the effect of stimulating pro-inflammatory effects would then marshal a general immune response [115]. Large clinical trials of $A \beta$ immunization in order to reduce $A \beta$ found a significant increase in encephalitis in those immunized [136], and similarly, infection increased in those treated to reduce $A \beta$ [137]. A summary noted that $A \beta$ formed plaques to trap pathogens and block invasion [138]. Membrane destabilization is another anti-pathogenic mechanism for $A \beta$ [139].

\section{C. albicans antigens and arteritis}

C. albicans antigens have been shown to induce arteritis [140], and giant cell arteritis is associated with cerebral amyloid deposits in the arteries [141] which suggests a connection between the development of $\mathrm{AD}$ and active $C$. albicans inflammation. In a study of candidemia in mice, a $C$. albicans water soluble beta glucan-mannoprotein complex exhibited significant cytotoxicity and injured the vascular endothelium through inflammatory response increasing production of IFN- $\alpha$, IL- 6 , and IL-10, and myeloperoxidase [142]. Together this accounts for arteritis and the resulting inflammation which would be aggravated by platelet aggregation and adhesion [143]. Note that glucan-mannoprotein complexes are a significant component in beer and ale [144].

\section{Immune evasion}

The ability of $C$. albicans to reside in endomycosomes [15] may be the result of biological selective pressure to survive identification and avoid destruction by the immune system. When host cells engulf C. albicans through phagocytosis, C. albicans alters its transcription toward starvation response with gluconeogenic growth, fatty acid beta oxidation (which consumes naturally anti-pathogenic short chain FFAs, free fatty acids), and reduction of ribosomal translation [145]. The immune system destroys pathogens by creating reactive oxygen species and free radicals (including $\bullet \mathrm{O}^{-}, \bullet \mathrm{OH}, \mathrm{ClO} \bullet$, and $\mathrm{NO} \bullet$ ) inside macrophage phagosomes, where $C$. albicans produces a catalase and six superoxide dismutases to neutralize reactive oxygen species and free radicals [146] and inhibit production of NO [147].

\section{Cholesterol esterification, LCAT}

LCAT (lecithin-cholesterol acyltransferase) is a glycoprotein enzyme responsible for esterifying cholesterol and is bound to high-density lipoproteins (HDL) or low-density lipoproteins (LDL). LCAT esterifies free cholesterol in the plasma, removes a fatty acid from the 2 glycerol position in phosphatidylcholine, and combines them. In doing this, LCAT changes the composition and conformation of HDL from compact, dense spheroid, or floppy discoid shapes, known variously as HDL3 and pre-beta, to a larger spheroid alpha shape that is able to contain the large and very hydrophobic cholesteryl ester in its core [148]. HDL slows progression of CVD by inhibiting cytokine induced expression of adhesion molecules that attach leukocytes to the endothelium [149] increasing adhesion to C. albicans. ApoE deficient mice producing depleted lipoproteins and increased VLDL show increased susceptibility to candidiasis because of increased virulence and reproduction due to uptake of plasma lipids as a growth medium [150]. 


\section{LCAT and the immune system}

Poorly functioning LCAT is correlated to a compromised immune system because LCAT esterifies cholesterol to antimicrobial fatty acids and transports the hydrophobic resultant into HDL. LCAT deficiency was found to reduce the ability of HDL to remove lipopolysaccharides (LPS) and aggravate LPS induced inflammation [151]. LCAT deficient HDL showed reduced levels of ApoA-I and ApoA-II and was primarily composed of ApoE. Additionally, reducing LCAT levels increased the number of monocytes in circulation after an LPS insult. The combined effect of poor removal of LPS, and the increase in monocytes produced a more severe inflammation. LCAT deficiency led to massive candidiasis in the upper respiratory system and mouth in a transplant patient with familial LCAT deficiency [152]. Inflammatory and anti-inflammatory responses can be contradictory, and one study on cholesteryl arachidonate/linoleate showed that they may induce inflammation [153].

FFAs inhibit microbes, and DHA and EPA kill many different cells [154]. The effect of LCPUFAs (long chain polyunsaturated fatty acids) is to destabilize lipid rafts in the following relative strength: "stearic acid $<$ oleic acid $<$ EPA $\leq$ DHA". The toxicity of triglycerides to monocyte-macrophages increases with increasing desaturation [155]:

"Triolean $=$ trilinolein $<$ trilinolenin $<$ triarachidonin $<$ tri-EPA = tri-DHA"

For the cholesterol esters, the order is: "cholesteryl linolenate $\sim$ cholesteryl oleate $<$ cholesteryl linoleate $<$ cholesteryl arachidonate $<$ cholesteryl EPA = cholesteryl DHA"

FFAs are toxic both to microbes and macrophages, and both compete to lipolyze triglycerides and cholesterol esters leaving free cholesterol. To survive, the macrophage must efflux the excess cholesterol, i.e., "HDL function" [156], in human macrophages [157].

Transporting lipids, especially LCPUFAs, to the site of inflammation/infection is important in infections, as they are active [158] against numerous pathogens, including Streptococcus mutans and $C$. albicans [159]. DHA facilitates lysozyme incorporation into the membrane of Pseudomonas aeruginosa bacteria, common in lung infections, which allows influx of more DHA, leading to bacterial cell death [160]. Many medium chain FFAs are antimicrobial against $C$. albicans [161], and more potent are short chain FFAs of which capric acid was applied as an antifungal [162].
C. albicans may enter into the cranial cavity through the nasopharyngeal nerve complex and then into the olfactory bulb, a region implicated in the early development of AD and dementia [163]. Oropharyngeal mucous contain the antimicrobial cholesteryl arachidonate, transported by HDL with other antipathogenic fatty acids fluids [127]. Arachidonic acid (AA) released by cPLA $2 \alpha$ has a demonstrated role in protecting the lung from $C$. albicans infection [164]. Since the brain is one of the largest stores of AA $[165,166]$, expect its availability to play a role in host defense against invasion by $C$. albicans. In the $\mathrm{AD}$ brain, there is an observable decrease in AA, EPA, and 22:4 [167]. Comparing the decrease in AA to the observation that $C$. albicans induces release of AA [54] suggests the conversion of AA to various oxidized metabolites that can affect $C$. albicans viability [168].

\section{LCAT and ApoE}

The biochemical relationship between ApoE and $\mathrm{AD}$ is significant because of the linked roles of LCAT and ApoE, both in the formation of HDL types and in the transportation of cholesterol, triglycerides, and cholesteryl esters. Coupling LCAT knockout mice with LDL receptor $(L D L r)$ knockout and $A P O E$ knockout, there is a notable reduction in HDL, an increase in LDL, and an increase in the saturation of cholesteryl esters in LDL [169] which resulted in significantly more cholesterol deposited in the aorta. A study of disseminated candidiasis in ApoE deficient mice [150] found increased mortality for ApoE deficiency, elevated lipids, and elevated apolipoproteins. Given that omega 3 fatty acids (which are antimicrobial) in the 2 position in phosphatidylcholine are preferentially esterified by LCAT, deficiency results in saturated lipids (and proteins) as food sources for Candida and an impaired immune response due to increasing saturation of FFAs.

The combined effects of LCAT and ApoE deficiency reduce the macrophage cholesterol efflux capacity of HDL and are a predictor of atherosclerotic CVD [170], and for $\mathrm{AD}$ the $A P O E-\varepsilon 4$ alleles are associated with degraded cholesterol efflux from macrophages. Similar to LCAT knockout, there is an increase in CVD for $A P O E-\varepsilon 4 / \varepsilon 4$ macrophages because of impaired efflux capacity [171]. Because excess cholesterol is considered toxic to macrophages and CNS astrocytes, sufficient cholesterol efflux will avoid loss of immune function. ApoE2 HDL exhibits delayed clearance because it interferes with the LDL receptor site and effluxes cholesterol more efficiently, 
and ApoE4 has the highest cellular reuptake of cholesterol [172].

\section{LCAT: $A D$ and Down's syndrome}

$\mathrm{AD}$ and Down's syndrome (DS) share similar characteristics, because after age 40, DS patients can develop aspects of AD [173]: amyloid deposition, deterioration of cognition, and reduction of the cholesterol esterification rate as serum cholesterol increases. Reduction of the fractional LCAT cholesterol esterification rate was the only difference observed in DS subjects [174]. DYRK1A kinase is overexpressed in DS due to trisomy 21 and activates STAT3 which affects LCAT expression and decreases LCAT activity because of activation a tyrosine phosphatase, SHP2 [175]. Similarly, for AD patients with dementia, LCAT esterification is also limited [176], and is perhaps due to the binding of $A \beta$ to HDL which inhibits LCAT [177].

\section{SUMMARY}

In the fungal model of $\mathrm{AD}$, defeat of the innate immune system allows colonization of neural cells with fungi. A $\beta$ is a natural antifungal and targeting its inhibition should be questioned, PUFAs and short chain FFAs inhibit infection, ApoE and LCAT function are interrelated, ingesting high levels of soluble beta glucans and chitin can interfere with fungal immunity, and untreated mycoses are problematic. Superior markers for AD are chitins and chitinase. Severe head injuries resulting in diffuse axonal injury, can result in fungal corpora amylacea that increase the risk of $\mathrm{AD}$.

Like a trojan horse, fungi defeat the innate immune system by hiding inside neural cells as endomycosomes. To control fungal and pathogenic infections in the brain, humans likely evolved an immune system that was just sufficient to attain reproductive age. Primitive man survived by sequestering fungi in neural cells instead of letting fungi reproduce and destroy the host. Sequestration was the only means to control fungal growth in a horrible diet that persorbed prodigious pathogens into human circulation and thence to the brain. Only now with improved diet and health these slower long-term debilities such as AD become manifest.

\section{ACKNOWLEDGMENTS}

The author thanks Prof. Bruce Ames for encouragement, Dr. Trudy Forte for her review of lipoproteins, and Luis Carrasco Llamas for offering updated research findings.

\section{CONFLICT OF INTEREST}

The author has no conflict of interest to report.

\section{REFERENCES}

[1] Alzheimer A (1907) Über eine eigenartige Erkrankung der Hirnrinde. Allg Z Psychiatr Psychiatr Gerichtl Med 64, 146-148.

[2] Dahm R (2006) Alzheimer's discovery. Curr Biol 16, R906-910.

[3] McMenemey WH (1940) Alzheimer's disease: A report of six cases. J Neurol Psychiatry 3, 211-240.

[4] Strich SJ (1956) Diffuse degeneration of the cerebral white matter in severe dementia following head injury. $J$ Neurol Neurosurg Psychiatry 19, 163-185.

[5] Lye TC, Shores EA (2000) Traumatic brain injury as a risk factor for Alzheimer's disease: A review. Neuropsychol Rev 10, 115-129.

[6] Cavanagh J (1999) Corpora-amylacea and the family of polyglucosan diseases. Brain Res Rev 29, 265-295.

[7] Mrak RE, Griffin ST, Graham DI (1997) Aging-associated changes in human brain. J Neuropathol Exp Neurol 56, 1269-1275.

[8] Keller JN (2006) Age-related neuropathology, cognitive decline, and Alzheimer's disease. Ageing Res Rev 5, 1-13.

[9] Schipper HM, Bennett DA, Liberman A, Bienias JL, Schneider JA, Kelly J, Arvanitakis Z (2006) Glial heme oxygenase-1 expression in Alzheimer disease and mild cognitive impairment. Neurobiol Aging 27, 252-261.

[10] Pisa D, Alonso R, Rabano A, Carrasco L (2016) Corpora amylacea of brain tissue from neurodegenerative diseases are stained with specific antifungal antibodies. Front $\mathrm{Neu}$ rosci 10, 86.

[11] Davidson EA, Robertson EE (1955) Alzheimer's disease with acne rosacea in one of identical twins. J Neurol Neurosurg Psychiatry 18, 72-77.

[12] Mawanda F, Wallace R (2013) Can infections cause Alzheimer's disease? Epidemiol Rev 35, 161-180.

[13] Beydoun MA, Beydoun HA, Gamaldo AA, Teel A, Zonderman AB, Wang Y (2014) Epidemiologic studies of modifiable factors associated with cognition and dementia: Systematic review and meta-analysis. BMC Public Health 14, 643 .

[14] Reitz C, Mayeux R (2014) Alzheimer disease: Epidemiology, diagnostic criteria, risk factors and biomarkers. Biochem Pharmacol 88, 640-651.

[15] Pisa D, Alonso R, Rabano A, Rodal I, Carrasco L (2015) Different brain regions are infected with fungi in Alzheimer's disease. Sci Rep 5, 15015.

[16] Pisa D, Alonso R, Juarranz A, Rabano A, Carrasco L (2015) Direct visualization of fungal infection in brains from patients with Alzheimer's disease. J Alzheimers Dis 43, 613-624.

[17] Alonso R, Pisa D, Rabano A, Carrasco L (2014) Alzheimer's disease and disseminated mycoses. Eur J Clin Microbiol Infect Dis 33, 1125-1132.

[18] Pisa D, Alonso R, Rabano A, Horst MN, Carrasco L (2016) Fungal enolase, beta-tubulin, and chitin are detected in 
brain tissue from Alzheimer's disease patients. Front Microbiol 7, 1772.

[19] Carrasco L, Alonso R, Pisa D, Rabano A (2017) Alzheimer's disease and fungal infection. In Handbook of Infection and Alzheimer's Disease, Miklossy J, ed. IOS Press, Amsterdam, pp. 281-294.

[20] Alonso R, Pisa D, Aguado B, Carrasco L (2017) Identification of fungal species in brain tissue from Alzheimer's disease by next-generation sequencing. J Alzheimers Dis 58, 55-67.

[21] Pisa D, Alonso R, Fernandez-Fernandez AM, Rabano A, Carrasco L (2017) Polymicrobial infections in brain tissue from Alzheimer's disease patients. Sci Rep 7, 5559.

[22] Emery DC, Shoemark DK, Batstone TE, Waterfall CM, Coghill JA, Cerajewska TL, Davies M, West NX, Allen SJ (2017) 16S rRNA next generation sequencing analysis shows bacteria in Alzheimer's post-mortem brain. Front Aging Neurosci 9, 195.

[23] Riedel K, Hentzer M, Geisenberger O, Huber B, Steidle A, Wu H, Hoiby N, Givskov M, Molin S, Eberl L (2001) N-acylhomoserine-lactone-mediated communication between Pseudomonas aeruginosa and Burkholderia cepacia in mixed biofilms. Microbiology 147, 3249-3262.

[24] Campos M, Marchini L, Bernardes L, Paulino L, Nobrega F (2008) Biofilm microbial communities of denture stomatitis. Oral Microbiol Immunol 23, 419-424.

[25] Adam B, Baillie GS, Douglas LJ (2002) Mixed species biofilms of Candida albicans and Staphylococcus epidermidis. J Med Microbiol 51, 344-349.

[26] de Rossi BP, Garcia C, Alcaraz E, Franco M (2014) Stenotrophomonas maltophilia interferes via the DSFmediated quorum sensing system with Candida albicans filamentation and its planktonic and biofilm modes of growth. Rev Argent Microbiol 46, 288-297.

[27] Glenner GG, Wong CW (1984) Alzheimer's disease: Initial report of the purification and characterization of a novel cerebrovascular amyloid protein. Biochem Biophys Res Commun 120, 885-890.

[28] Selkoe DJ, Hardy J (2016) The amyloid hypothesis of Alzheimer's disease at 25 years. EMBO Mol Med 8, 595608.

[29] Atwood CS, Bowen RL (2015) A unified hypothesis of early-and late-onset Alzheimer's disease pathogenesis. J Alzheimers Dis 47, 33-47.

[30] Serrano-Pozo A, Frosch MP, Masliah E, Hyman BT (2011) Neuropathological alterations in Alzheimer disease. Cold Spring Harb Perspect Med 1, a006189.

[31] Castellani RJ, Lee H-g, Zhu X, Perry G, Smith MA (2008) Alzheimer disease pathology as a host response. J Neuropathol Exp Neurol 67, 523-531.

[32] Plummer S, Van den Heuvel C, Thornton E, Corrigan F, Cappai R (2016) The Neuroprotective properties of the amyloid precursor protein following traumatic brain injury. Aging Dis 7, 163-179.

[33] Gilchrist KB, Garcia MC, Sobonya R, Lipke PN, Klotz SA (2012) New features of invasive candidiasis in humans: Amyloid formation by fungi and deposition of serum amyloid P component by the host. J Infect Dis 206, 1473-1478.

[34] Eriksen N, Ericsson LH, Pearsall N, Lagunoff D, Benditt EP (1976) Mouse amyloid protein AA: Homology with nonimmunoglobulin protein of human and monkey amyloid substance. Proc Natl Acad Sci U S A 73, 964-967.

[35] Ramsook CB, Tan C, Garcia MC, Fung R, Soybelman G, Henry R, Litewka A, O'Meally S, Otoo HN, Khalaf RA, Dranginis AM, Gaur NK, Klotz SA, Rauceo JM, Jue
CK, Lipke PN (2010) Yeast cell adhesion molecules have functional amyloid-forming sequences. Eukaryot Cell $\mathbf{9}$, 393-404.

[36] Divry P (1927) Etude histochimique des plaques seniles. J Belge Neurol Psychiat 27, 643-657.

[37] Luse SA, Smith KR Jr (1964) The ultrastructure of senile plaques. Am J Pathol 44, 553-563.

[38] Kimura M, Asada T, Uno M, Machida N, Kasuya K, Taniguchi Y, Fujita T, Nishiyama E, Iwamoto N, Arai H (1999) Assessment of cerebrospinal fluid levels of serum amyloid $\mathrm{P}$ component in patients with Alzheimer's disease. Neurosci Lett 273, 137-139.

[39] Dong Y, Zhang G, Zhang B, Moir RD, Xia W, Marcantonio ER, Culley DJ, Crosby G, Tanzi RE, Xie Z (2009) The common inhalational anesthetic sevoflurane induces apoptosis and increases beta-amyloid protein levels. Arch Neurol 66, 620-631.

[40] Liu C, Liu Y, Shen Z, Miao L, Zhang K, Wang F, Li $Y$ (2015) Sevoflurane preconditioning reduces intestinal ischemia-reperfusion injury: Role of protein kinase $\mathrm{C}$ and mitochondrial ATP-sensitive potassium channel. PLoS One 10, e141426.

[41] Krause W, Matheis H, Wulf K (1969) Fungaemia and funguria after oral administration of Candida albicans. Lancet 1, 598-599.

[42] Sepulveda FJ, Parodi J, Peoples RW, Opazo C, Aguayo LG (2010) Synaptotoxicity of Alzheimer beta amyloid can be explained by its membrane perforating property. PLoS One 5, e11820.

[43] Kagan BL, Jang H, Capone R, Teran Arce F, Ramachandran S, Lal R, Nussinov R (2012) Antimicrobial properties of amyloid peptides. Mol Pharm 9, 708-717.

[44] Kumar DK, Choi SH, Washicosky KJ, Eimer WA, Tucker S, Ghofrani J, Lefkowitz A, McColl G, Goldstein LE, Tanzi RE, Moir RD (2016) Amyloid-beta peptide protects against microbial infection in mouse and worm models of Alzheimer's disease. Sci Transl Med $\mathbf{8}$, $340 \mathrm{ra} 372$.

[45] Teich AF, Arancio O (2012) Is the amyloid hypothesis of Alzheimer's disease therapeutically relevant? Biochem J 446, 165-177.

[46] Salloway S, Sperling R, Keren R, Porsteinsson AP, van Dyck CH, Tariot PN, Gilman S, Arnold D, Abushakra S, Hernandez C, Crans G, Liang E, Quinn G, Bairu M, Pastrak A, Cedarbaum JM (2011) A phase 2 randomized trial of ELND005, scyllo-inositol, in mild to moderate Alzheimer disease. Neurology 77, 1253-1262.

[47] Cleve EA, Smith FP (1957) Infections complicating cortisone therapy. N Engl J Med 256, 104-108.

[48] Sidransky H, Pearl MA (1961) Pulmonary fungus infections associated with steroid and antibiotic therapy. Dis Chest 39, 630-642.

[49] Lowe D (2010) Lilly's gamma secretase inhibitor for Alzheimer's: Worse than nothing. In Corante. In the Pipeline, http://pipeline.corante.com/archives/2010/08/ 18/lillys_gamma_secretase_inhibitor_for_alzheimers_ worse_than_nothing.php

[50] Mullane K, Williams M (2013) Alzheimer's therapeutics: Continued clinical failures question the validity of the amyloid hypothesis-but what lies beyond? Biochem Pharmacol 85, 289-305.

[51] Lee VM, Goedert M, Trojanowski JQ (2001) Neurodegenerative tauopathies. Annu Rev Neurosci 24, 1121-1159.

[52] Vega IE, Cui L, Propst JA, Hutton ML, Lee G, Yen SH (2005) Increase in tau tyrosine phosphorylation correlates 
with the formation of tau aggregates. Brain Res Mol Brain Res 138, 135-144.

[53] Morsch R, Simon W, Coleman PD (1999) Neurons may live for decades with neurofibrillary tangles. J Neuropathol Exp Neurol 58, 188-197.

[54] Alonso Adel C, Li B, Grundke-Iqbal I, Iqbal K (2006) Polymerization of hyperphosphorylated tau into filaments eliminates its inhibitory activity. Proc Natl Acad Sci U S A 103, 8864-8869.

[55] Bartus RT, Dean RL 3rd, Beer B, Lippa AS (1982) The cholinergic hypothesis of geriatric memory dysfunction. Science 217, 408-414.

[56] Klig LS, Friedli L, Schmid E (1990) Phospholipid biosynthesis in Candida albicans: Regulation by the precursors inositol and choline. J Bacteriol 172, 4407-4414.

[57] Greenberg ML, Lopes JM (1996) Genetic regulation of phospholipid biosynthesis in Saccharomyces cerevisiae. Microbiol Rev 60, 1-20.

[58] Klein J, Gonzalez R, Koppen A, Loffelholz K (1993) Free choline and choline metabolites in rat brain and body fluids: Sensitive determination and implications for choline supply to the brain. Neurochem Int 22, 293-300.

[59] McCool L (2010) Discovery and naming of Candida albicans. http://www.antimicrobe.org/h04c.files/history/ DiscoveryNaming\%20of\%20Candida\%20albicans.asp

[60] Plaut HC, Grutz O (1928) Die hyphenpilzeoder eumyceten. In Handbuch der Pathogenen Mikroorganismen; 3rd Edition, Kolle VW, Kraus R, Uhlenhuth P, eds. Gustav Fischer, Jena, pp. 133-320.

[61] Jasch KC, Hermes B, Scheller U, Harth W (2008) Pyoderma gangrenosum-like primary cutaneous cryptococcosis. Acta Derm Venereol 88, 76-77.

[62] Ruggieri M, Polizzi A, Vitaliti MC, Magro G, Musumeci S (1999) Fatal biphasic brainstem and spinal leptomeningitis with Cryptococcus neoformans in a nonimmunocompromised child. Acta Paediatr 88, 671-674.

[63] Brown P, Demaerel P, McNaught A, Revesz T, Graham E, Kendall BE, Plant G (1994) Neuro-ophthalmological presentation of non-invasive Aspergillus sinus disease in the non-immunocompromised host. J Neurol Neurosurg Psychiatry 57, 234-237.

[64] Walsh TJ, Groll A, Hiemenz J, Fleming R, Roilides E, Anaissie E (2004) Infections due to emerging and uncommon medically important fungal pathogens. Clin Microbiol Infect 10 Suppl 1, 48-66.

[65] Barelle CJ, Priest CL, Maccallum DM, Gow NA, Odds FC, Brown AJ (2006) Niche-specific regulation of central metabolic pathways in a fungal pathogen. Cell Microbiol 8, 961-971.

[66] Lorenz MC, Fink GR (2002) Life and death in a macrophage: Role of the glyoxylate cycle in virulence. Eukaryot Cell 1, 657-662.

[67] Lorenz MC, Fink GR (2001) The glyoxylate cycle is required for fungal virulence. Nature 412, 83-86.

[68] Sudbery PE (2011) Growth of Candida albicans hyphae. Nat Rev Microbiol 9, 737-748.

[69] Rodrigues AG, Mardh PA, Pina-Vaz C, Martinez-deOliveira J, Fonseca AF (1999) Germ tube formation changes surface hydrophobicity of Candida cells. Infect Dis Obstet Gynecol 7, 222-226.

[70] Silva TM, Glee PM, Hazen KC (1995) Influence of cell surface hydrophobicity on attachment of Candida albicans to extracellular matrix proteins. J Med Vet Mycol 33, 117-122.
[71] Heineman HS, Yunis EJ, Siemienski J, Braude AI (1961) Chlamydospores and dimorphism in Candida albicans endocarditis. Observations in a fatal superinfection during treatment of staphylococcus endocarditis. Arch Intern Med 108, 570-577.

[72] Alasio TM, Lento PA, Bottone EJ (2003) Giant blastoconidia of Candida albicans. A case report and review of the literature. Arch Pathol Lab Med 127, 868-871.

[73] Bottone EJ, Horga M, Abrams J (1999) "Giant" blastoconidia of Candida albicans: Morphologic presentation and concepts regarding their production. Diagn Microbiol Infect Dis 34, 27-32.

[74] Mayer FL, Wilson D, Hube B (2013) Candida albicans pathogenicity mechanisms. Virulence 4, 119-128.

[75] Hube B (1996) Candida albicans secreted aspartyl proteinases. Curr Top Med Mycol 7, 55-69.

[76] Butler G, Rasmussen MD, Lin MF, Santos MA, Sakthikumar S, Munro CA, Rheinbay E, Grabherr M, Forche A, Reedy JL, Agrafioti I, Arnaud MB, Bates S, Brown AJ, Brunke S, Costanzo MC, Fitzpatrick DA, de Groot PW, Harris D, Hoyer LL, Hube B, Klis FM, Kodira C, Lennard N, Logue ME, Martin R, Neiman AM, Nikolaou E, Quail MA, Quinn J, Santos MC, Schmitzberger FF, Sherlock G, Shah P, Silverstein KA, Skrzypek MS, Soll D, Staggs R, Stansfield I, Stumpf MP, Sudbery PE, Srikantha T, Zeng Q, Berman J, Berriman M, Heitman J, Gow NA, Lorenz MC, Birren BW, Kellis M, Cuomo CA (2009) Evolution of pathogenicity and sexual reproduction in eight Candida genomes. Nature 459, 657-662.

[77] Calderone RA, Fonzi WA (2001) Virulence factors of Candida albicans. Trends Microbiol 9, 327-335.

[78] Ahearn DG (1978) Medically important yeasts. Annu Rev Microbiol 32, 59-68.

[79] Hube B, Sanglard D, Odds FC, Hess D, Monod M, Schafer W, Brown AJ, Gow NA (1997) Disruption of each of the secreted aspartyl proteinase genes SAP1, SAP2, and SAP3 of Candida albicans attenuates virulence. Infect Immun $\mathbf{6 5}$, 3529-3538.

[80] Phan QT, Myers CL, Fu Y, Sheppard DC, Yeaman MR, Welch WH, Ibrahim AS, Edwards JE Jr, Filler SG (2007) Als 3 is a Candida albicans invasin that binds to cadherins and induces endocytosis by host cells. PLoS Biol 5, e64.

[81] Dalle F, Wachtler B, L'Ollivier C, Holland G, Bannert N, Wilson D, Labruere C, Bonnin A, Hube B (2010) Cellular interactions of Candida albicans with human oral epithelial cells and enterocytes. Cell Microbiol 12, 248-271.

[82] Moyes DL, Runglall M, Murciano C, Shen C, Nayar D, Thavaraj S, Kohli A, Islam A, Mora-Montes H, Challacombe SJ, Naglik JR (2010) A biphasic innate immune MAPK response discriminates between the yeast and hyphal forms of Candida albicans in epithelial cells. Cell Host Microbe 8, 225-235.

[83] Hofs S, Mogavero S, Hube B (2016) Interaction of Candida albicans with host cells: Virulence factors, host defense, escape strategies, and the microbiota. J Microbiol 54, 149169.

[84] Moyes DL, Wilson D, Richardson JP, Mogavero S, Tang SX, Wernecke J, Hofs S, Gratacap RL, Robbins J, Runglall M, Murciano C, Blagojevic M, Thavaraj S, Forster TM, Hebecker B, Kasper L, Vizcay G, Iancu SI, Kichik N, Hader A, Kurzai O, Luo T, Kruger T, Kniemeyer O, Cota E, Bader O, Wheeler RT, Gutsmann T, Hube B, Naglik JR (2016) Candidalysin is a fungal peptide toxin critical for mucosal infection. Nature 532, 64-68. 
[85] Tucey TM, Verma-Gaur J, Nguyen J, Hewitt VL, Lo TL, Shingu-Vazquez M, Robertson AA, Hill JR, Pettolino FA, Beddoe T, Cooper MA, Naderer T, Traven A (2016) The endoplasmic reticulum-mitochondrion tether ERMES orchestrates fungal immune evasion, illuminating inflammasome responses to hyphal signals. mSphere 1, e00074-16.

[86] Tomalka J, Ganesan S, Azodi E, Patel K, Majmudar P, Hall BA, Fitzgerald KA, Hise AG (2011) A novel role for the NLRC4 inflammasome in mucosal defenses against the fungal pathogen Candida albicans. PLoS Pathog 7, e1002379.

[87] Wellington M, Koselny K, Sutterwala FS, Krysan DJ (2014) Candida albicans triggers NLRP3-mediated pyroptosis in macrophages. Eukaryot Cell 13, 329-340.

[88] Filler SG, Sheppard DC (2006) Fungal invasion of normally non-phagocytic host cells. PLoS Pathog 2, e129.

[89] Jong AY, Stins MF, Huang SH, Chen SH, Kim KS (2001) Traversal of Candida albicans across human blood-brain barrier in vitro. Infect Immun 69, 4536-4544.

[90] Vylkova S, Carman AJ, Danhof HA, Collette JR, Zhou H, Lorenz MC (2011) The fungal pathogen Candida albicans autoinduces hyphal morphogenesis by raising extracellular pH. MBio 2, e00055-00011.

[91] Kvamme E (1983) Ammonia metabolism in the CNS. Prog Neurobiol 20, 109-132.

[92] Seiler N (2002) Ammonia and Alzheimer's disease. Neurochem Int 41, 189-207.

[93] Hoyer S, Nitsch R, Oesterreich K (1990) Ammonia is endogenously generated in the brain in the presence of presumed and verified dementia of Alzheimer type. Neurosci Lett 117, 358-362.

[94] Ship JA, DeCarli C, Friedland RP, Baum BJ (1990) Diminished submandibular salivary flow in dementia of the Alzheimer type. J Gerontol 45, M61-66.

[95] Alosco ML, Duskin J, Besser LM, Martin B, Chaisson CE, Gunstad J, Kowall NW, McKee AC, Stern RA, Tripodis Y (2017) Modeling the relationships among late-life body mass index, cerebrovascular disease, and Alzheimer's disease neuropathology in an autopsy sample of 1,421 subjects from the National Alzheimer's Coordinating Center Data Set. J Alzheimers Dis 57, 953-968.

[96] Knight L, Fletcher J (1971) Growth of Candida albicans in saliva: Stimulation by glucose associated with antibiotics, corticosteroids, and diabetes mellitus. J Infect Dis 123, 371-377.

[97] Samaranayake LP, MacFarlane TW (1981) The adhesion of the yeast Candida albicans to epithelial cells of human origin in vitro. Arch Oral Biol 26, 815-820.

[98] Hube B, Stehr F, Bossenz M, Mazur A, Kretschmar M, Schafer W (2000) Secreted lipases of Candida albicans: Cloning, characterisation and expression analysis of a new gene family with at least ten members. Arch Microbiol 174, 362-374.

[99] Niewerth M, Korting HC (2001) Phospholipases of Candida albicans. Mycoses 44, 361-367.

[100] Paraje MG, Correa SG, Renna MS, Theumer M, Sotomayor CE (2008) Candida albicans-secreted lipase induces injury and steatosis in immune and parenchymal cells. Can J Microbiol 54, 647-659.

[101] Correa SG, Rodriguez-Galan MC, Salido-Renteria B, Cano R, Cejas H, Sotomayor CE (2004) High dissemination and hepatotoxicity in rats infected with Candida albicans after stress exposure: Potential sensitization to liver damage. Int Immunol 16, 1761-1768.
[102] Bader T, Bodendorfer B, Schroppel K, Morschhauser J (2003) Calcineurin is essential for virulence in Candida albicans. Infect Immun 71, 5344-5354.

[103] Cruz MC, Goldstein AL, Blankenship JR, Del Poeta M, Davis D, Cardenas ME, Perfect JR, McCusker JH, Heitman J (2002) Calcineurin is essential for survival during membrane stress in Candida albicans. EMBO J 21, 546559.

[104] Goto S, Hirano A, Matsumoto S (1990) Immunohistochemical study of the striatal efferents and nigral dopaminergic neurons in parkinsonism-dementia complex on Guam in comparison with those in Parkinson's and Alzheimer's diseases. Ann Neurol 27, 520-527.

[105] Furman JL, Norris CM (2014) Calcineurin and glial signaling: Neuroinflammation and beyond. J Neuroinflammation 11, 158.

[106] Kumar A, Singh N (2017) Calcineurin inhibitors improve memory loss and neuropathological changes in mouse model of dementia. Pharmacol Biochem Behav 153, 147159.

[107] Taglialatela G, Rastellini C, Cicalese L (2015) Reduced incidence of dementia in solid organ transplant patients treated with calcineurin inhibitors. J Alzheimers Dis 47, 329-333.

[108] Sugita T, Tajima M, Ito T, Saito M, Tsuboi R, Nishikawa A (2005) Antifungal activities of tacrolimus and azole agents against the eleven currently accepted Malassezia species. J Clin Microbiol 43, 2824-2829.

[109] MacCallum DM (2009) Massive induction of innate immune response to Candida albicans in the kidney in a murine intravenous challenge model. FEMS Yeast Res $\mathbf{9}$, 1111-1122.

[110] Belanger PH, Johnston DA, Fratti RA, Zhang M, Filler SG (2002) Endocytosis of Candida albicans by vascular endothelial cells is associated with tyrosine phosphorylation of specific host cell proteins. Cell Microbiol 4, 805-812.

[111] De Felice FG, Wu D, Lambert MP, Fernandez SJ, Velasco PT, Lacor PN, Bigio EH, Jerecic J, Acton PJ, Shughrue PJ, Chen-Dodson E, Kinney GG, Klein WL (2008) Alzheimer's disease-type neuronal tau hyperphosphorylation induced by A beta oligomers. Neurobiol Aging 29, 1334-1347.

[112] Watabe-Rudolph M, Song Z, Lausser L, Schnack C, Begus-Nahrmann Y, Scheithauer MO, Rettinger G, Otto M, Tumani H, Thal DR, Attems J, Jellinger KA, Kestler HA, von Arnim CA, Rudolph KL (2012) Chitinase enzyme activity in CSF is a powerful biomarker of Alzheimer disease. Neurology 78, 569-577.

[113] Castellani RJ, Siedlak SL, Fortino AE, Perry G, Ghetti B, Smith MA (2005) Chitin-like polysaccharides in Alzheimer's disease brains. Curr Alzheimer Res 2, 419-423.

[114] Di Rosa M, Dell'Ombra N, Zambito AM, Malaguarnera M, Nicoletti F, Malaguarnera L (2006) Chitotriosidase and inflammatory mediator levels in Alzheimer's disease and cerebrovascular dementia. Eur J Neurosci 23, 2648-2656.

[115] Soscia SJ, Kirby JE, Washicosky KJ, Tucker SM, Ingelsson M, Hyman B, Burton MA, Goldstein LE, Duong S, Tanzi RE, Moir RD (2010) The Alzheimer's disease-associated amyloid beta-protein is an antimicrobial peptide. PLoS One 5, e9505.

[116] Rosen C, Andersson CH, Andreasson U, Molinuevo JL, Bjerke M, Rami L, Llado A, Blennow K, Zetterberg H (2014) Increased levels of chitotriosidase and YKL-40 in 
cerebrospinal fluid from patients with Alzheimer's disease. Dement Geriatr Cogn Dis Extra 4, 297-304.

[117] Siaens R, Eijsink VG, Dierckx R, Slegers G (2004) (123)I-Labeled chitinase as specific radioligand for in vivo detection of fungal infections in mice. J Nucl Med 45, 1209-1216.

[118] Labadaridis I, Dimitriou E, Theodorakis M, Kafalidis G, Velegraki A, Michelakakis H (2005) Chitotriosidase in neonates with fungal and bacterial infections. Arch Dis Child Fetal Neonatal Ed 90, F531-532.

[119] Ostrosky-Zeichner L, Alexander BD, Kett DH, Vazquez J, Pappas PG, Saeki F, Ketchum PA, Wingard J, Schiff R, Tamura H, Finkelman MA, Rex JH (2005) Multicenter clinical evaluation of the (1->3) beta-D-glucan assay as an aid to diagnosis of fungal infections in humans. Clin Infect Dis 41, 654-659.

[120] Karageorgopoulos DE, Vouloumanou EK, Ntziora F, Michalopoulos A, Rafailidis PI, Falagas ME (2011) Beta-D-glucan assay for the diagnosis of invasive fungal infections: A meta-analysis. Clin Infect Dis 52, 750-770.

[121] Mikulska M, Furfaro E, Del Bono V, Raiola AM, Di Grazia C, Bacigalupo A, Viscoli C (2013) (1-3)-beta-D-glucan in cerebrospinal fluid is useful for the diagnosis of central nervous system fungal infections. Clin Infect Dis 56, 15111512.

[122] Malani AN, Singal B, Wheat LJ, Al Sous O, Summons TA, Durkin MM, Pettit AC (2015) (1,3)-beta-d-glucan in cerebrospinal fluid for diagnosis of fungal meningitis associated with contaminated methylprednisolone injections. J Clin Microbiol 53, 799-803.

[123] Netea MG, van Tits LJ, Curfs JH, Amiot F, Meis JF, van der Meer JW, Kullberg BJ (1999) Increased susceptibility of TNF-alpha lymphotoxin-alpha double knockout mice to systemic candidiasis through impaired recruitment of neutrophils and phagocytosis of Candida albicans. J Immunol 163, 1498-1505.

[124] Pfaller MA, Diekema DJ, Gibbs DL, Newell VA, Meis JF, Gould IM, Fu W, Colombo AL, Rodriguez-Noriega E (2007) Results from the ARTEMIS DISK Global Antifungal Surveillance study, 1997 to 2005: An 8.5-year analysis of susceptibilities of Candida species and other yeast species to fluconazole and voriconazole determined by CLSI standardized disk diffusion testing. J Clin Microbiol 45, 1735-1745.

[125] Cheng SC, Joosten LA, Kullberg BJ, Netea MG (2012) Interplay between Candida albicans and the mammalian innate host defense. Infect Immun 80, 1304-1313.

[126] Miramon P, Dunker C, Windecker H, Bohovych IM, Brown AJ, Kurzai O, Hube B (2012) Cellular responses of Candida albicans to phagocytosis and the extracellular activities of neutrophils are critical to counteract carbohydrate starvation, oxidative and nitrosative stress. PLoS One 7, e52850.

[127] Do TQ, Moshkani S, Castillo P, Anunta S, Pogosyan A, Cheung A, Marbois B, Faull KF, Ernst W, Chiang SM, Fujii G, Clarke CF, Foster K, Porter E (2008) Lipids including cholesteryl linoleate and cholesteryl arachidonate contribute to the inherent antibacterial activity of human nasal fluid. J Immunol 181, 4177-4187.

[128] Zavrel M, Hoot SJ, White TC (2013) Comparison of sterol import under aerobic and anaerobic conditions in three fungal species, Candida albicans, Candida glabrata, and Saccharomyces cerevisiae. Eukaryot Cell 12, 725-738.
[129] Mosadeghzad Z, Zuriati Z, Asmat A, Gires U, Wickneswari R, Pittayakhajonwut P, Farahani GHN (2013) Chemical components and bioactivity of the marinederived fungus Paecilomyces sp. Collected from Tinggi Island, Malaysia. Chem Nat Compd 48, 621-625.

[130] Zago CE, Silva S, Sanita PV, Barbugli PA, Dias CM, Lordello VB, Vergani CE (2015) Dynamics of biofilm formation and the interaction between Candida albicans and methicillin-susceptible (MSSA) and -resistant Staphylococcus aureus (MRSA). PLoS One 10, e0123206.

[131] Muresan A (1960) A case of cerebral mucormycosis diagnosed in life. with eventual recovery. J Clin Pathol 13, 34-36.

[132] Hosseini SM, Borghei P (2005) Rhinocerebral mucormycosis: Pathways of spread. Eur Arch Otorhinolaryngol 262, 932-938.

[133] Kathuria MK, Gupta RK (2001) Fungal infections, Springer Science \& Business Media.

[134] Parker JC Jr, McCloskey JJ, Lee RS (1978) The emergence of candidosis. The dominant postmortem cerebral mycosis. Am J Clin Pathol 70, 31-36.

[135] Lathe R, Sapronova A, Kotelevtsev Y (2014) Atherosclerosis and Alzheimer-diseases with a common cause? Inflammation, oxysterols, vasculature. BMC Geriatr 14, 36.

[136] Weksler ME, Gouras G, Relkin NR, Szabo P (2005) The immune system, amyloid-beta peptide, and Alzheimer's disease. Immunol Rev 205, 244-256.

[137] Green RC, Schneider LS, Amato DA, Beelen AP, Wilcock G, Swabb EA, Zavitz KH (2009) Effect of tarenflurbil on cognitive decline and activities of daily living in patients with mild Alzheimer disease: A randomized controlled trial. JAMA 302, 2557-2564.

[138] Stilling RM, Cryan JF (2016) Host response: A trigger for neurodegeneration? Nat Microbiol 1, 16129.

[139] Williams TL, Serpell LC (2011) Membrane and surface interactions of Alzheimer's Abeta peptide-insights into the mechanism of cytotoxicity. FEBS J 278, 3905-3917.

[140] Murata H (1979) Experimental candida-induced arteritis in mice. Relation to arteritis in the mucocutaneous lymph node syndrome. Microbiol Immunol 23, 825-831.

[141] Anders KH, Wang ZZ, Kornfeld M, Gray F, Soontornniyomkij V, Reed LA, Hart MN, Menchine M, Secor DL, Vinters HV (1997) Giant cell arteritis in association with cerebral amyloid angiopathy: Immunohistochemical and molecular studies. Hum Pathol 28, 1237-1246.

[142] Ohno N (2003) Chemistry and biology of angiitis inducer, Candida albicans water-soluble mannoproteinbeta-glucan complex (CAWS). Microbiol Immunol 47, 479-490.

[143] Skerl KG, Calderone RA, Sreevalsan T (1981) Platelet interactions with Candida albicans. Infect Immun 34, 938-943.

[144] Moran CA (2004) Functional components of the cell wall of Saccharomyces cerevisiae: Applications for yeast glucan and mannan. In Nutritional biotechnology in the feed and food industries. Proceedings of Alltech's 20th Annual Symposium: Re-imagining the feed industry Alltech UK., Lexington, Kentucky, pp. 283-296.

[145] Lorenz MC, Bender JA, Fink GR (2004) Transcriptional response of Candida albicans upon internalization by macrophages. Eukaryot Cell 3, 1076-1087.

[146] Jimenez-Lopez C, Lorenz MC (2013) Fungal immune evasion in a model host-pathogen interaction: Candida albicans versus macrophages. PLoS Pathog 9, e1003741. 
[147] Schroter C, Hipler UC, Wilmer A, Kunkel W, Wollina U (2000) Generation of reactive oxygen species by Candida albicans in relation to morphogenesis. Arch Dermatol Res 292, 260-264.

[148] Dieplinger H, Zechner R, Kostner GM (1985) The in vitro formation of HDL2 during the action of LCAT: The role of triglyceride-rich lipoproteins. J Lipid Res 26, 273-282.

[149] Cockerill GW, Rye KA, Gamble JR, Vadas MA, Barter PJ (1995) High-density lipoproteins inhibit cytokine-induced expression of endothelial cell adhesion molecules. Arterioscler Thromb Vasc Biol 15, 1987-1994.

[150] Vonk AG, De Bont N, Netea MG, Demacker PN, van der Meer JW, Stalenhoef AF, Kullberg BJ (2004) Apolipoprotein-E-deficient mice exhibit an increased susceptibility to disseminated candidiasis. Med Mycol 42, 341-348.

[151] Petropoulou PI, Berbee JF, Theodoropoulos V, Hatziri A, Stamou P, Karavia EA, Spyridonidis A, Karagiannides I, Kypreos KE (2015) Lack of LCAT reduces the LPSneutralizing capacity of HDL and enhances LPS-induced inflammation in mice. Biochim Biophys Acta 1852, 21062115.

[152] Stokke KT, Bjerve KS, Blomhoff JP, Oystese B, Flatmark A, Norum KR, Gjone E (1974) Familial lecithin:Cholesterol acyltransferase deficiency. Studies on lipid composition and morphology of tissues. Scand J Clin Lab Invest Suppl 137, 93-100.

[153] Adam O, Beringer C, Kless T, Lemmen C, Adam A, Wiseman M, Adam P, Klimmek R, Forth W (2003) Antiinflammatory effects of a low arachidonic acid diet and fish oil in patients with rheumatoid arthritis. Rheumatol Int 23, 27-36.

[154] Gorjao R, Azevedo-Martins AK, Rodrigues HG, Abdulkader F, Arcisio-Miranda M, Procopio J, Curi R (2009) Comparative effects of DHA and EPA on cell function. Pharmacol Ther 122, 56-64.

[155] Hardwick SJ, Carpenter KL, Law NS, Van Der Veen C, Marchant CE, Hird R, Mitchinson MJ (1997) Toxicity of polyunsaturated fatty acid esters for human monocytemacrophages: The anomalous behaviour of cholesteryl linolenate. Free Radic Res 26, 351-362.

[156] Khera AV, Cuchel M, de la Llera-Moya M, Rodrigues A, Burke MF, Jafri K, French BC, Phillips JA, Mucksavage ML, Wilensky RL, Mohler ER, Rothblat GH, Rader DJ (2011) Cholesterol efflux capacity, high-density lipoprotein function, and atherosclerosis. N Engl J Med 364, 127-135.

[157] Yvan-Charvet L, Wang N, Tall AR (2010) Role of HDL, ABCA1, and ABCG1 transporters in cholesterol efflux and immune responses. Arterioscler Thromb Vasc Biol 30, 139-143.

[158] Huang CB, Ebersole JL (2010) A novel bioactivity of omega-3 polyunsaturated fatty acids and their ester derivatives. Mol Oral Microbiol 25, 75-80.

[159] Huang CB, George B, Ebersole JL (2010) Antimicrobial activity of n-6, n-7 and n-9 fatty acids and their esters for oral microorganisms. Arch Oral Biol 55, 555-560.

[160] Martinez JG, Waldon M, Huang Q, Alvarez S, Oren A, Sandoval N, Du M, Zhou F, Zenz A, Lohner K, Desharnais R, Porter E (2009) Membrane-targeted synergistic activity of docosahexaenoic acid and lysozyme against Pseudomonas aeruginosa. Biochem J 419, 193-200.

[161] Kabara JJ, Swieczkowski DM, Conley AJ, Truant JP (1972) Fatty acids and derivatives as antimicrobial agents. Antimicrob Agents Chemother 2, 23-28.
[162] Bergsson G, Arnfinnsson J, Steingrimsson O, Thormar H (2001) In vitro killing of Candida albicans by fatty acids and monoglycerides. Antimicrob Agents Chemother 45, 3209-3212.

[163] Roberts RO, Christianson TJ, Kremers WK, Mielke MM, Machulda MM, Vassilaki M, Alhurani RE, Geda YE, Knopman DS, Petersen RC (2016) Association between olfactory dysfunction and amnestic mild cognitive impairment and Alzheimer Disease dementia. JAMA Neurol 73, 93-101.

[164] Balestrieri B, Maekawa A, Xing W, Gelb MH, Katz HR, Arm JP (2009) Group V secretory phospholipase A2 modulates phagosome maturation and regulates the innate immune response against Candida albicans. J Immunol 182, 4891-4898.

[165] Svennerholm L (1964) The distribution of lipids in the human nervous system. I. Analytical procedure. Lipids of foetal and newborn brain. J Neurochem 11, 839-853.

[166] Crawford MA, Sinclair AJ (1971) Nutritional influences in the evolution of mammalian brain. In: Lipids, malnutrition $\&$ the developing brain. Ciba Found Symp, 267-292.

[167] Soderberg M, Edlund C, Kristensson K, Dallner G (1991) Fatty acid composition of brain phospholipids in aging and in Alzheimer's disease. Lipids 26, 421-425.

[168] Noverr MC, Phare SM, Toews GB, Coffey MJ, Huffnagle GB (2001) Pathogenic yeasts Cryptococcus neoformans and Candida albicans produce immunomodulatory prostaglandins. Infect Immun 69, 2957-2963.

[169] Furbee JW Jr, Sawyer JK, Parks JS (2002) Lecithin:Cholesterol acyltransferase deficiency increases atherosclerosis in the low density lipoprotein receptor and apolipoprotein E knockout mice. J Biol Chem 277, 3511-3519.

[170] Rohatgi A, Khera A, Berry JD, Givens EG, Ayers CR, Wedin KE, Neeland IJ, Yuhanna IS, Rader DR, de Lemos JA, Shaul PW (2014) HDL cholesterol efflux capacity and incident cardiovascular events. N Engl J Med 371, 23832393.

[171] Cullen P, Cignarella A, Brennhausen B, Mohr S, Assmann G, von Eckardstein A (1998) Phenotype-dependent differences in apolipoprotein E metabolism and in cholesterol homeostasis in human monocyte-derived macrophages. J Clin Invest 101, 1670-1677.

[172] Davignon J, Gregg RE, Sing CF (1988) Apolipoprotein E polymorphism and atherosclerosis. Arteriosclerosis 8, $1-21$.

[173] Knebl J, DeFazio P, Clearfield MB, Little L, McConathy WJ, McPherson R, Lacko AG (1994) Plasma lipids and cholesterol esterification in Alzheimer's disease. Mech Ageing Dev 73, 69-77.

[174] Lacko AG, Hayes JD, McConathy WJ, Lacko I, Redheendran R (1983) Lecithin: Cholesterol acyltransferase in Down's syndrome. Clin Chim Acta 132, 133-141.

[175] Tlili A, Noll C, Middendorp S, Duchon A, Jouan M, Benabou E, Herault Y, Paul JL, Delabar JM, Janel N (2013) DYRK1A overexpression decreases plasma lecithin:Cholesterol acyltransferase activity and apolipoprotein A-I levels. Mol Genet Metab 110, 371-377.

[176] Demeester N, Castro G, Desrumaux C, De Geitere C, Fruchart JC, Santens P, Mulleners E, Engelborghs S, De Deyn PP, Vandekerckhove J, Rosseneu M, Labeur C (2000) Characterization and functional studies of lipoproteins, lipid transfer proteins, and lecithin:Cholesterol acyltransferase in CSF of normal individuals and 
patients with Alzheimer's disease. J Lipid Res 41, 963-974.

[177] Koudinov AR, Koudinova NV, Berezov TT (1996) Alzheimer's peptides A beta 1-40 and A beta 1-28 inhibit the plasma cholesterol esterification rate. Biochem $\mathrm{Mol}$ Biol Int 38, 747-752. 